\title{
Seasonal spermatogenesis and testosterone production in roe deer (Capreolus capreolus)
}

\author{
S. Blottner, O. Hingst and H. H. D. Meyer \\ Institute for Zoo Biology and Wildlife Research, Alfred-Kowalke-Strasse 17, 10315 Berlin, Germany
}

\begin{abstract}
Quantitative changes in testes of roe deer were studied during the annual cycle. Testicular spermatozoa were counted and proportions of different cell types were estimated using DNA flow cytometry. A proliferation-specific antigen of somatic cells was evaluated by an immunoradiometric assay. Apoptosis was examined by cell death detection ELISA, and testosterone concentrations were measured with an enzymeimmunoassay. The testis mass of adults reached a maximum during the rut from mid-July to mid-August. Gonadal size corresponded to numbers of testicular spermatozoa $\mathrm{g}^{-1}$ testis. In the rutting period, epididymal spermatozoa were of the highest morphological and functional competence. The proportions of haploid (Ic), diploid (2c) and tetraploid (4c) cells changed over time with the maximum of $1 \mathrm{c}$ cells during the breeding period. Meiotic division ( $1 \mathrm{c}: 4 \mathrm{c}$ ratio) increased sharply immediately before rut, while mitosis (\% cells in G2-M phase) was already high during spring. Proliferation and apoptosis revealed an opposite pattern during the annual cycle; the most intensive apoptosis occurred during the time of testis involution. Testosterone production showed a biphasic pattern. It dropped rapidly from the highest value in August to very low concentrations thereafter. Yearlings were characterized by smaller peaks of testicular growth and sperm production. Fawns started testicular growth and meiosis in winter. In conclusion, the production of spermatozoa in roe deer is intensified by enlargement of gonads as well as enhanced efficiency of spermatogenesis during the rut. Interrupted proliferation and stimulated apoptosis promote testis involution after the rut, and testosterone seems to play a role in the regulation of both processes.
\end{abstract}

\section{Introduction}

Many mammals living in cold and temperate climates have evolved seasonal reproductive strategies that ensure adaptation to annual changes in the environment and which minimize the energetic costs of their reproductive efforts. The role of environmental signals in synchronization has been described in many investigations, especially the circannual regulation of pituitary and gonadal function by photoperiod (for reviews see Bronson, 1988; Lincoln, 1989). Resulting seasonal changes of cellular composition and processes in testes have been studied in only a few mammalian species such as hamsters (Bergmann et al., 1990; van Haaster et al., 1993; Lerchl et al., 1993) and horses (Johnson, 1991, 1995).

The roe deer is a seasonally breeding species characterized by a short rutting season from mid-July to mid-August. Mature males show highly synchronized testicular cycles including transitions between totally arrested and highly activated spermatogenesis. Studies in roe deer have shown this annual cycle of involution and recrudescence of testes in connection with plasma concentrations of hormone and their interaction with antler growth (Brüggemann et al., 1965; Sempéré and Boisson, 1981; Sempere et al., 1992). Some investigations have also

Received 3 April 1996. demonstrated seasonal changes in the histology of male gonads and showed that the testes are devoid of all signs of spermatogenic activity during the winter months (Stieve, 1950; Hartung and Schoppmeyer, 1986; Marchlewska-Koj and Kruczek, 1988; Gentile et al., 1989). However, a quantitative characterization of changing cellular composition and the interaction of proliferative and apoptotic processes in testes of roe deer is not available. Therefore, the aim of this study was to measure seasonal changes of different cell types, mitotic, meiotic and apoptotic activity and testosterone production of testes in roe deer using flow cytometry and biochemical markers for proliferation and apoptosis.

\section{Materials and Methods}

\section{Animals}

A total of 114 roe deer were studied from May 1994 until January of 1996, including 68 adults, 26 yearlings and 20 fawns. The testes were collected immediately after hunting, cooled to $4-6^{\circ} \mathrm{C}$ for transport and prepared in the laboratory within $24 \mathrm{~h}$ after removal from the animals. Parameters of epididymal spermatozoa were not included if the time between testis collection and preparation was longer than $12 \mathrm{~h}$. 


\section{Preparation of testes}

The testes and epididymides were separated and the testes were weighed. The number of testicular spermatozoa was determined in suspensions prepared by carefully pressing $0.2 \mathrm{~g}$ of decapsulated testis through a $28 \mu \mathrm{m}$ nylon mesh with $4 \mathrm{ml}$ medium M199 supplemented with $0.4 \%(\mathrm{w} / \mathrm{v})$ BSA (Sigma, Deisenhofen). The germ cell suspension was diluted in the same volume of water and counted with a haemocytometer. Results are given as spermatozoa $\mathrm{g}^{-1}$ testis.

Aliquots of decapsulated testicular tissue $(1 \mathrm{~g})$ were minced and homogenized by freezing-thawing three times in $2 \mathrm{ml}$ PBS buffer and by subsequent sonification at $4^{\circ} \mathrm{C}$ for $1 \mathrm{~min}$. Identical aliquots were used for quantification of both testicular proliferation and apoptosis. Proliferation-specific soluble protein and apoptosis-derived nucleosomes from the cytoplasm were obtained in supernatants of testis homogenates after centrifugation $\left(30 \mathrm{~min}\right.$ at $25000 \mathrm{~g}, 4^{\circ} \mathrm{C}$ ). Sample aliquots were stored at $-80^{\circ} \mathrm{C}$ if they were not tested on the same day.

\section{Collection and evaluation of epididymal spermatozoa}

Spermatozoa were collected from finely minced caput, corpus and cauda epididymides. They were washed in Hanks' balanced salt solution and resuspended in medium M199 (Sigma, Deisenhofen). After incubation at $37^{\circ} \mathrm{C}$ for $15 \mathrm{~min}$, the percentage of progressively motile spermatozoa from the cauda epididymides was evaluated by phase-contrast microscopy. Smears of the same samples were prepared for morphological evaluation. The number of normal spermatozoa per 400 cells ( 200 cells per slide) of each sample was counted after staining with aqueous solutions of Congo red (saturated) for $2 \mathrm{~min}, 2 \%(\mathrm{w} / \mathrm{v})$ tannic acid for $3 \mathrm{~min}$ and $2.5 \%(\mathrm{w} / \mathrm{v})$ brilliant cresyl blue for $30 \mathrm{~s}$. The slides were rinsed between the staining steps and air-dried after staining.

Chromatin stability and DNA resistance to acidic denaturation was evaluated by acidic acridine orange staining of spermatozoa from different regions of the epididymis according to the method of Tejada et al. (1984). The fixed and stained smears were examined (heads of 200 spermatozoa per slide, two slides for each sample) immediately after the staining procedure using a reflecting-light fluorescence microscope (Jenalumar, Carl Zeiss Jena, Germany). The spermatozoa were categorized according to their green or red fluorescence. The percentage of cells with green fluorescence (double-stranded DNA) represents the denaturation-resistant spermatozoa.

\section{Histology}

For histological examples, small pieces of testicular parenchyma were fixed in paraformaldehyde, embedded in Technovit 7100 (Heraeus Kulzer $\mathrm{GmbH}$, Wehrheim) and cut $8 \mu \mathrm{m}$ in thickness. The specimens were stained using a standard haematoxylin and eosin method.

\section{Flow cytometric DNA analysis}

Testicular cells were prepared according to the method of Otto as described in the user protocol (Partec $\mathrm{GmbH}$, Münster) without the fixation step: the cells were dispersed by finely mincing $0.1 \mathrm{~g}$ of decapsulated testis tissue in $1 \mathrm{ml} 2.1 \%(\mathrm{w} / \mathrm{v})$ citric acid $\cdot \mathrm{H}_{2} \mathrm{O}$ and $0.5 \%(\mathrm{v} / \mathrm{v})$ Tween 20 . The released nuclei were dispersed by gentle agitation for $20 \mathrm{~min}$ and stained with $5 \mathrm{ml} \mathrm{0.175 \% (w/v)} \mathrm{4',6-diamidino-2-phenylindol} \mathrm{(DAPI;} \mathrm{Sigma,}$ Deisenhofen) in $7.1 \%(\mathrm{w} / \mathrm{v}) \mathrm{Na}_{2} \mathrm{HPO}_{4} \cdot 2 \mathrm{H}_{2} \mathrm{O}$. The flow cytometric analysis was performed in a PAS III flow cytometer (Partec $\mathrm{GmbH}$, Münster) with a mercury lamp using a $360 \mathrm{~nm}$ wavelength for excitation and $420 \mathrm{~nm}$ for emission. Approximately $5-10 \times 10^{4}$ cells were measured in each sample. The DNA histograms obtained were analysed for proportions of cells in each peak and for mitotic cell cycle by DPAC computer software. The content of haploid, diploid and tetraploid cells were expressed as Ic, $2 \mathrm{c}$ and $4 \mathrm{c}$ percentages.

\section{Immunoradiometric assay for proliferation-specific tissue polypeptide antigen}

Testicular proliferation was quantified also by using the tissue polypeptide specific antigen (TPS) as a proliferationspecific marker. TPS represents a cytokeratin 18 fragment which is recognized by a monoclonal antibody in an immunoradiometric assay (IRMA) or ELISA ( Beki, Stockholm). The cytokeratin and its degradation products are indicative of somatic cells in testes, because spermatogenic cells express no intermediate filaments of this type (Moll, 1993; Steger et al., 1994). Previous studies showed the correlation between TPS and the developmental stage of animals or the seasonal involution and recrudescence of testes (Blottner et al., 1994). The amount of TPS was measured in the homogenized testicular parenchyma as described in these studies. The measured values were expressed in units $\mathrm{g}^{-1}$ testis $\left(\mathrm{U} \mathrm{g}^{-1}\right)$.

\section{Cell death detection ELISA}

The apoptosis was characterized by assessment of nucleosomes released from apoptotic cells according to the protocol of Hingst and Blottner (1995). The cell death detection assay (Boehringer, Mannheim; Germany) is based on a quantitative sandwich enzymeimmunoassay allowing the specific determination of mono- and oligonucleosomes in the cytoplasmic fraction of cell homogenates. The results were given in units (absorbance) per $\mathrm{mg}$ testis $\left(\mathrm{U} \mathrm{mg}^{-1}\right.$ ). The samples of homogenized tissue were diluted to final concentrations of $1-100 \mu \mathrm{g}$ testis equivalent $(100 \mu \mathrm{l})^{-1}$ sample, and $100 \mu \mathrm{l}$ of each sample solution was used in duplicate.

\section{Estimation of testosterone by EIA}

Testicular testosterone was measured by enzymeimmunoassay with a double antibody technique as described by Meyer and Hoffmann (1987). Briefly, triplicates of $200 \mu \mathrm{g}$ tissue were extracted with $1 \mathrm{ml}$ ethanol/water $70 / 30(\mathrm{v} / \mathrm{v})$. The extract was diluted with assay buffer as required; then $2 \times 20 \mu \mathrm{l}$ were analysed. The assay used a polyclonal antibody raised in rabbits against testosterone-11-hemisuccinate-BSA, and the label was testosterone-3-carboxymethyl-oxime-horseradish peroxidase. The testosterone standard curve ranged from $0.4 \mathrm{pg}(20 \mu \mathrm{l})^{-1}$ to $50 \mathrm{pg}(20 \mu \mathrm{l})^{-1}$ and the crossreactivity 

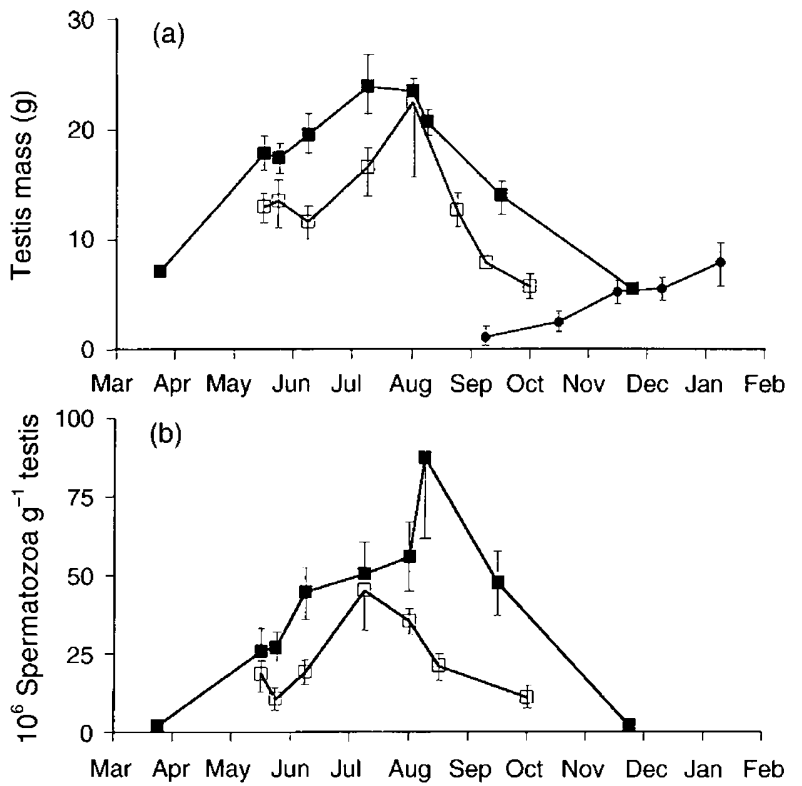

Fig. 1. Testis mass (a) and testicular spermatozoa concentration (b) in adults ( $\boldsymbol{\square})$, yearlings $(\square)$ and fawns $(\mathbf{O})$ of roe deer during the annual cycle from March to February. The results are expressed as means \pm SEM. Where no error bar is shown it is within the symbol.

with testosterone was $100 \%$, with $5 \alpha$-dihydrotestosterone $10 \%$, with androstenedione $2 \%$, with oestradiol $<0.1 \%$ and with progesterone $<0.1 \%$.

\section{Statistical analysis}

The measured parameters were assessed over the course of the annual cycle. Therefore, results of animals obtained within 5 to 8 days were combined (means of 2-16 animals per date). The lower numbers of available data from epididymal spermatozoa were combined for the pre-rutting (May), rutting (late July-early August) and post-rutting (September-October) periods. They were subjected to analysis of variance (ANOVA) and subsequently to a paired test of means with the Bonferroniadjustment for the significance level of $P=0.05$.

\section{Results}

Testis mass and testicular spermatozoa

The highest testicular masses of adult animals and yearlings were found in the rutting period from late July to early August (Fig. 1a). Testes of yearlings begin to grow later and involution starts earlier than in adults. Gonadal development of fawns was not stimulated until the period of high regression of older individuals. However, adults and yearlings were not available for a direct comparison in December and January.

Gonadal size corresponded to the number of testicular spermatozoa $\mathrm{g}^{-1}$ parenchyma and also showed marked differences between adults and yearlings (Fig. $\mathrm{Ib}$ ). Thus, the production of spermatozoa was increased in the rut by both the enlargement of the testicular tissue and the enhanced spermatogenic capacity of tissue.

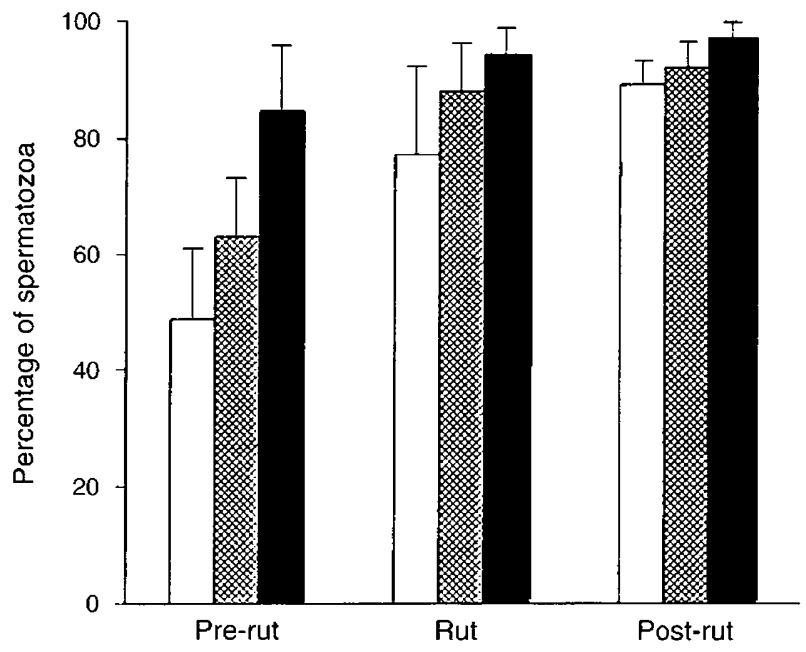

Fig. 2. Percentages (means \pm SEM) of spermatozoa with denaturationresistant DNA (green fluorescence after acridine orange staining) from caput ( $\square$ ), corpus (网) and cauda ( $\square$ ) epididymides of roe deer in breeding and non-breeding seasons.

Significant production of spermatozoa in fawns begins in January: five of 20 fawns showed some testicular spermatozoa in the period between September and December, while spermatozoa were found in each of the three fawns from January, with an average of $28.67 \pm 23.03 \times 10^{6} \mathrm{~g}^{-1}$ testis. The total spermatozoa in both cauda epididymides of these fawns was $61.2 \pm 89.9 \times 10^{6}$. (In comparison, the total spermatozoa of adult bucks during the rut was $336-3075 \times 10^{\circ}$.)

Proportions of morphologically normal and functionally competent spermatozoa were higher during the rutting period than in other periods, indicating optimal conditions for spermatogenesis. The stability of chromatin in spermatozoa entering the caput epididymis was significantly lower $(P<0.001)$ in the pre-rutting time (Fig. 2). The percentage of motile spermatozoa from cauda epididymis differed significantly $(P<0.01)$ between the breeding $(67.8 \pm 23.1 \% ; n=16)$ and the preceding $(46.7 \pm 20.9 \% ; n=18)$ or subsequent $(30.4 \pm 27.2 \% ; n=6)$ period. The proportions of morphologically normal spermatozoa in the rutting, pre- and post-rutting time were $62.3 \pm 14.4 \%, 52.1 \pm 19.1 \%$ and $38.0 \pm 28.5 \%$, respectively. The difference in these percentages between rutting and post-rutting period was significant $(P<0.05)$.

\section{Histological evaluation}

Examples of cross-sections of seminiferous tubules were evaluated for histological comparison of adult animals before (May, $n=5$ ), during (August, $n=5$ ) and after (November, $n=2$ ) the rut. In May, the samples already showed all stages of the spermatogenic cycle with moderate meiotic activity. Rutting animals were characterized by a thick layer of germinal epithelium and large numbers of round and elongated spermatids per cross-section of tubule. In November, roe deer with highly involuted testes showed tubules aligned only by Sertoli cells and spermatogonia. Numbers of round and elongated spermatids per cross-section of tubule differed between the pre-rutting (52 \pm 20 and $33 \pm 18)$ and the rutting $(86 \pm 29$ and 

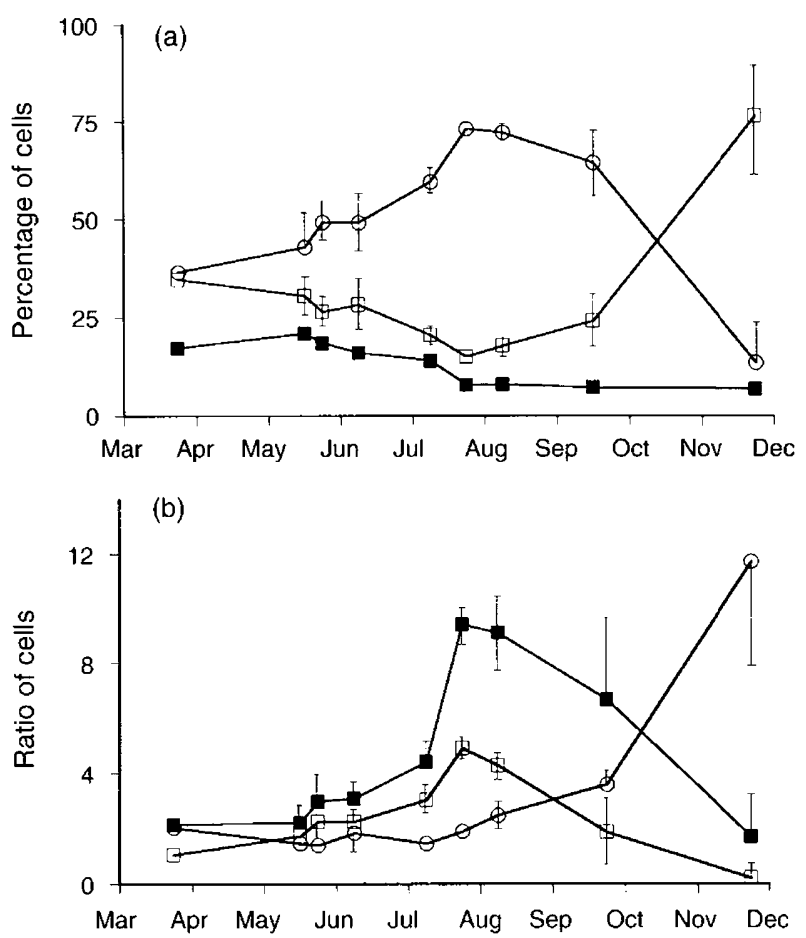

Fig. 3. Seasonally changing DNA-content (ploidy) of testicular cells in adult roe deer analysed by flow cytometry (means \pm SEM). (a) Proportions of haploid (O), diploid $(\square)$ and tetraploid ( $(\mathbf{a})$ cells. (b) Ratios of cells with the different ploidy level: $1 \mathrm{c} / 4 \mathrm{c}(\boldsymbol{\square}), 1 \mathrm{c} / 2 \mathrm{c}(\square)$ and $2 \mathrm{c} / 4 \mathrm{c}$ (O). Error bars that are not shown are contained within the data point.

$104 \pm 25)$ period. The difference of elongated spermatids was significant $(P<0.05)$.

\section{Testicular cell populations with different DNA content}

The proportions of cells with different ploidy levels changed continuously over time (Fig. 3a). The highest percentage of haploid cells was reached during the rut with a range of 67.8 to $77.8 \%$ in late July-early August $(n=12)$. The ratios of these cell types elucidated the characteristics of the breeding period (Fig. 3b). Meiotic division (1c:4c ratio) showed a sharp increase immediately before this period. In contrast, the percentage of cells in G2-M phase of mitosis (Fig. 4) demonstrated that mitosis in adult animals was highly activated in spring and already decreased during the rut reaching the lowest value in winter. The calculation is based on all diploid, DNA synthesizing and tetraploid cells and therefore includes the cells of the somatic compartment, which increase before the rut. The activation of mitosis in yearlings was confined to a shorter phase in the seasonal cycle, and fawns did not show a marked increase of mitosis before the end of the year.

\section{Proliferation-specific antigen and apoptosis}

Changes in proliferation of somatic cells and apoptosis showed an opposite pattern during transition from pre-rutting to post-rutting period (Fig. 5). The highest amount of proliferation-specific TPS was found during the breeding

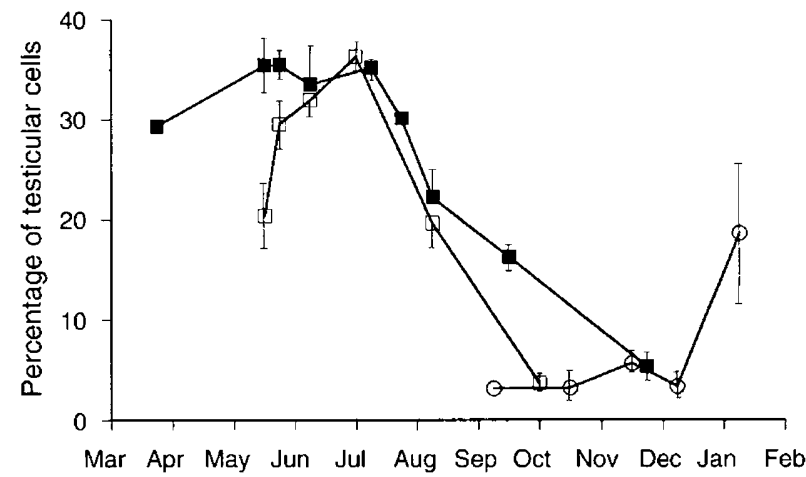

Fig. 4. Percentage (means \pm SEM) of testicular cells in the G2-M phase of mitotic cell cycle in adults $(\boldsymbol{\square})$, yearlings $(\square)$ and fawns $(O)$ of roe deer during different seasonal periods.

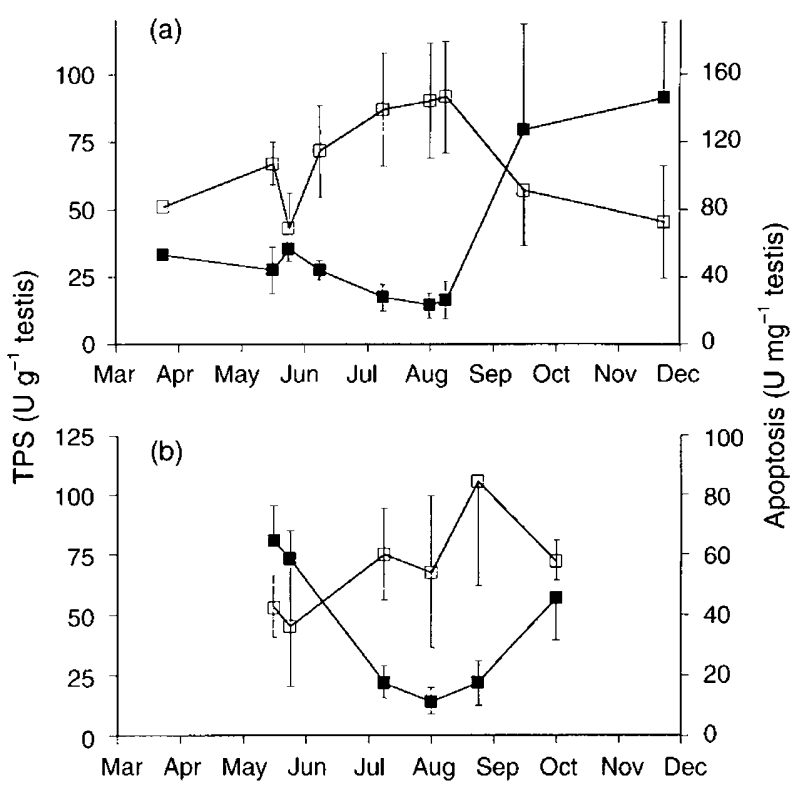

Fig. 5. Content (means \pm SEM) of proliferation-specific tissue polypeptide antigen TPS ( $\square$ ) and apoptosis-specific nucleosomes ( $\boldsymbol{\square}$ ) in homogenized testicular cells of (a) adult and (b) yearling roe deer.

season for both adults and yearlings if compared to the non-breeding periods. This antigen seems to occur in a biphasic pattern during the annual cycle. In contrast, the most intensive apoptosis was observed in the non-breeding season. The steep rise of apoptosis in adult roe deer (Fig. 5a) corresponded to the time of testis involution.

The TPS concentration of fawns increased during the time of intensified testis growth in December and January with high individual variations between 10.9 and $324.1 \mathrm{U} \mathrm{g}^{-1}$. In this time the mean apoptosis was $17.95 \pm 11.60 \mathrm{U} \mathrm{mg}^{-1}(n=8)$, which is comparable to that of adults during the rut.

\section{Testosterone concentration}

Testicular testosterone concentration showed a biphasic pattern with some differences between adults and yearlings (Fig. 6). Testosterone production of adult roe deer increased 


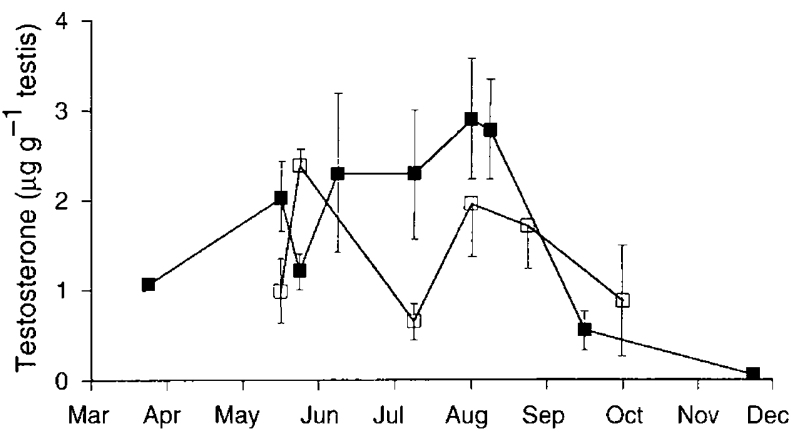

Fig. 6. Seasonal dependence of testicular testosterone concentrations (means \pm SEM) in adult $(\boldsymbol{\square})$ and yearling $(\square)$ roe deer.

during the second rise to the highest value of $2.89 \pm 1.51 \mu \mathrm{g}$ $\mathrm{g}^{-1}$ testis (first week of August; $n=10$ ) coinciding with peak sperm production (Fig. 1b). Subsequently, its concentration dropped rapidly to $0.06 \pm 0.03 \mu \mathrm{g} \mathrm{g}^{-1}$ in November. The most intensive testosterone production of yearlings was found in the first peak preceding the breeding season.

\section{Discussion}

The results of this study demonstrate the interacting alterations of proliferation, apoptosis and hormone production in testis of roe deer during the annual cycle.

The cyclic alternation between growth and involution of testes is a well-known phenomenon and the seasonality of testis mass shown in this study is in general agreement with extensive reports in this species (Stieve, 1950; Hartung and Schoppmeyer, 1986; Marchlewska-Koj and Kruczek, 1988). An activated testis growth in fawns during October and November and following involution in December and January as reported by Hartung and Schoppmeyer (1986) was not confirmed by our findings of continuous development in this period. This discrepancy could be the result of the smaller sample size of our study; it also suggests possible influences of different climatic conditions. The course of testis growth and the low numbers of testicular and epididymal spermatozoa suggest that none of the fawns reached their fertilizing capacity in the time studied.

The flow cytometric analysis of mitotic and meiotic steps in the testicular tissue provides an exact estimation of quantitative changes in cellular composition. Spermatogenesis is connected with distinct changes in DNA content of cells and DNA flow cytometry was validated as a simplified, sensitive and highly objective method of determining spermatogenesis (HackerKlom et al., 1986; Suresh et al. 1992; Hirsch et al., 1993). The data of this study reveal that the percentage of haploid cells, in accordance with the estimated number of testicular spermatozoa per gram of tissue, increases continuously for some months until the rut. However, meiosis is intensively activated only immediately before the rut. Thereafter the mitotic and meiotic cell divisions decrease very rapidly, indicated by an inhibition in the transformations of $2 \mathrm{c}$ cells to primary spermatocytes (4c) and of primary spermatocytes to spermatids (1c) a few weeks later. This decrease in dividing activities coincided with a pronounced reduction of testosterone production and an extensive rise of apoptosis.
The highest testosterone concentrations occurred simultaneously with the highest proliferation and the lowest apoptosis. Testosterone production was biphasic. This pattern was more evident in yearlings than in adults. A biphasic increase of testosterone in peripheral plasma seems to be characteristic in roe deer during sexual maturation as well as during the reproductive cycle in mature animals (Gimenez et al., 1975). Our results also agree with data of Schams and Barth (1982) and Sempére et al. (1992), showing that the hormone concentration of adult roe deer rose in February and reached a peak in July, prior to the rut.

Testosterone is necessary to maintain normal spermatogenesis in mature animals. An important function of the androgen is the conversion of round to elongated spermatids in the rat (O'Donnell et al., 1994). Above all, specific testosterone deprivation led to an immediate arrest in the meiotic transformation of $4 \mathrm{c}$ to Ic cells resulting in an effective block in sperm production, as is evident from flow cytometry studies in bonnet monkeys (Suresh et al., 1995) and rabbits (Jeyakumar et al., 1995). Our data are in accordance with these evidences of testosterone regulated spermatogenesis at specific germ cell transformation steps. The FSH was not recorded, but this gonadotrophin influences the spermatogenesis in mammals via stimulation of Sertoli cells. In roe deer FSH declines in June to low values in the post-breeding season (Schams and Barth, 1982). A lack of stimulation of spermatogenesis can be expected at this time. Experimental FSH deprivation caused a $90 \%$ reduction in $1 \mathrm{c}$ cells in the rat testis (Vaishnav and Moudgal, 1994). The Djungarian hamster reacts to shortening photoperiods by decreased release of $\mathrm{LH}$ and FSH. The resulting arrest of spermatogenesis can be selectively restimulated up to the level of round spermatids by exogenous FSH administration (Lerchl et al., 1993).

Testosterone also plays an essential role in preventing apoptotic cell death in androgen-dependent tissues (reviewed in Tenniswood et al., 1992; Thompson, 1994). Apoptosis is a basic mechanism for signal-induced, selective cell elimination. The survival of spermatogenic cells is dependent on gonadotrophins as well as intratesticular androgens induced by $\mathrm{LH}$ (Tapanainen et al., 1993; Troiano et al., 1994; Billig et al., 1995; Sinha Hikim et al., 1995; Marathe et al., 1995). Round spermatids and pachytene spermatocytes in rats were found to be the germ cells most sensitive to the lack of $\mathrm{LH}$ and underwent apoptosis (Marathe et al., 1995; Sinha-Hikim et al., 1995). The onset of apoptosis of spermatogenic cells depends also on the developmental stage of the animal (Billig et al., 1995).

Proliferation with spontaneous degeneration of spermatogenic cells seems to be a general property of normal mammalian testes (Allan et al., 1987; Kerr, 1992). Seasonal alterations of spermatogenesis were demonstrated as a function of changes in the number of both spermatogonia and degenerating cells in the stallion (Johnson, 1995) and Eld's deer (Monfort et al., 1993). Consequently, apoptosis could play an important role in the seasonal regulation of male gonads, especially as an efficient mechanism to adjust the energy budget by testicular involution. This assumption is supported by the opposite patterns of apoptosis and proliferation within the annual cycle of roe deer in this study. Similar situations were observed in brown hares (Blottner et al., 1995). Markedly enhanced testicular apoptosis was also reported for 
photoperiod-induced testis regression in Djungarian hamsters (Furuta et al., 1994) and for seasonally determined sexual dormancy in a tropical bat (Onyango et al., 1995). Therefore, an inverse relationship between proliferation and apoptosis in testicular parenchyma seems to serve a basic regulatory principle in seasonally breeding mammals.

In addition, testosterone also modulates growth and metabolism in several peripheral tissues that contain androgen receptors such as skeletal muscle (Sauerwein and Meyer, 1989). In muscular tissue, androgens stimulate cell hypertrophy to glycolytic white muscle cells possibly via reduction in glucocorticoid sensitivity (Sauerwein et al., 1991) and reduced proteolytic enzyme activities (Florini, 1987). Glycolytic ATP production needs more energy providing substrates and the rapid drop of testosterone concentrations after the rut enables the animal to produce ATP more economically by substrate oxidation. Also in this respect, the regulatory events in male roe deer reproduction are optimized for minimal energy expenditure.

All these results reveal the subtle coordination of different processes in testes to guarantee the success of reproduction with an optimal relation between investment and efficiency. Precise timing under pineal-pituitary control ensures that high fertilizing capacity is not obtained until the rut and then only. The last steps of spermatogenesis, the transformation of primary spermatocytes to spermatids and then to spermatozoa, are activated at the highest level immediately before and during the breeding period. At this time, the number of dividing spermatogonia is reduced again and the proportion of cells in G2-M phase starts to decline drastically. After the rut, energy-consuming processes are significantly diminished, while energy-saving processes are activated.

In conclusion, the production of spermatozoa in roe deer is intensified by enlargement of gonads as well as enhanced efficiency of spermatogenesis during the rut. The significant involution of testes after the rut results from both a cessation of proliferation in seminiferous tubules and a stimulation of apoptosis, and testosterone seems to play a role in the regulation of both processes.

The authors thank N. C. Pratt from the National Zoological Park, Smithsonian Institution, Washington D.C., for critical reading of the manuscript. The studies were supported by a grant from Deutsche Forschungsgemeinschaft (Bl 319/3-1).

\section{References}

Allan DJ, Harmon BV and Kerr JFR (1987) Cell death in spermatogenesis. In Perspective on Mammalian Cell Death pp 229-258. Oxford University Press, London

Bergmann M, Kumari M, Aumüller G, Hoffmann K and Seitz J (1990) Distribution pattern of testicular sulphydryloxidase immuno-activity in the Djungarian hamster (Phodopus sungorus) during photoperiodically induced involution and recrudescence International Journal of Androlology 13 488-499

Billig H, Furuta I, Rivier C, Tapanainen J, Parvinen M and Hsueh AJW (1995) Apoptosis in testis germ cells: developmental changes in gonadotropin dependence and localization to selective tubule stages Endocrinology 136 $5-12$

Blottner S, Blottner A, Hingst O and Schadow D (1994). Use of TPS as a proliferation marker in studies of mammalian spermatogenesis. In Current Tumor diagnosis: Applications, Research, Trends pp 285-288 Ed. R Klapdor. Zuckschwerdt-Verlag, München, Bern, Wien, New York
Blottner S, Hingst $O$ and Meyer HHD (1995) Inverse relationship between testicular proliferation and apoptosis in mammalian seasonal breeders Theriogenology 44 320-328

Bronson FH (1988) Seasonal regulation of reproduction in mammals. In The Physiology of Reproduction Vol. 2, pp 1831-1871 Eds E Knobil E and JD Neill. Raven Press, New York

Brüggemann J, Adam A and Karg H (1965) ICSH-Bestimmungen in Hypophysen von Rehböcken (Capreolus capreolus) und Hirschen (Cervus elaphus) unter Berücksichtigung des Saisoneinflusses Acta Endocrinologica 48 569-580

Florini JR (1987) Hormonal control of muscle growth Muscle \& Nerve 10 $577-598$

Furuta I, Porkka-Heiskanen T, Scarbrough K, Tapanainen J, Turek FW and Hsueh AJW (1994) Photoperiod regulates testis cell apoptosis in Djungarian hamsters Biology of Reproduction 51 1315-1321

Gentile R, Scisciola V, Lenti M and Passantino G (1989) Microanatomical features about the biological cycle of roe deer and roe buck Capreolus capreolus Bolletino Societa Italiana Biologia Sperimentale 65 631-638

Gimenez T, Barth D, Hoffmann B and Karg H (1975) Blood levels of testosterone in the roe deer Capreolus capreolus in relationship to the season Acta Endocrinologia, Supplement, 13959

Hacker-Klom U, Ritter J and Kleinhans G (1986) DNA-analysis of human testicular samples by cytofluorometry Andrologia 18 304-311

Hartung J and Schoppmeyer K (1986) Zur zyklischen Entwicklung der Hoden beim Reh Beirräge zur Jagd-und Wildforschung 14 214-221

Hingst $\mathbf{O}$ and Blottner S (1995) Quantification of apoptosis (programmed cell death) in mammalian testes by DNA-fragmentation ELISA Theriogenology 44 313-319

Hirsch IH, McCue P, Kulp-Hugues D, Sedor J and Flanigan M (1993) Validation of flow cytometry analysis in the objective assessment of spermatogenesis: comparison to the quantitative testicular biopsy Journal of Urology $\mathbf{1 5 0}$ 342-346

Jeyakumar M, Suresh R, Krishnamurthy HN and Moudgal NR (1995) Changes in testicular function following specific deprivation of $\mathrm{LH}$ in the adult male rabbit Journal of Endocrinology 147 111-120

Johnson L (1991) Seasonal differences in equine spermatogenesis Biology of Reproduction 44 284-291

Johnson L (1995) Efficiency of spermatogenesis Microscopy Research and Technigue $32 \quad 385-422$

Kerr JB (1992) Spontaneous degeneration of germ cells in normal rat testis: assessment of cell types and frequency during the spermatogenic cycle Journal of Reproduction and Fertility 95 825-830

Lerchl A, Sotiriadou S, Behre HM, Pierce J, Weinbauer GF, Kliesch S and Nieschlag E (1993) Restoration of spermatogenesis by follicle-stimulating hormone despite low intratesticular testosterone in photo-inhibited hypogonadotropic Djungarian hamsters (Phodopus sungarus) Biology of Reproduction $491108-1116$

Lincoln GA (1989) Seasonal aspects of testicular function In The Testis Pp 329-386 Eds H Burger and D de Kretser, Raven Press, New York

Marathe GK, Shetty J and Dighe RR (1995) Selective immunoneutralization of luteinizing hormone results in the apoptotic cell death of pachytene spermatocytes and spermatids in the rat testis Endocrine 3 705-709

Marchlewska-Koj A and Kruczek M (1988) Seasonal variation in testicular activity of roe deer Capreolus capreolus Folia Biologica (Warszawa) 36 $119-126$

Meyer HHD and Hoffmann B ( 1987) Development of a sensitive microtiterplate enzyme immunoassay for the anabolic steroid trenbolone Food Additives and Contaminants 4 149-160

Moll R (1993) Cytokeratins as Markers of Differentiation. Expression Profiles in Epithelia and Epithelial Tumors Gustav Fischer Verlag, Stuttgart, Jena, New York

Monfort SL, Brown JL, Bush TC, Wood TC, Wemmer C, Vargas A, Williamson LR, Montali RJ and Wildt DE (1993) Circannual interrelationships among reproductive hormones, gross morphometry, behaviour, ejaculate characteristics and testicular histology in Eld's deer stags (Cervus eldi thamin) Journal of Reproduction and Fertility 98 471-480

O'Donnell L, Mclachlan RI, Wreford NG, Robertson DM (1994) Testosterone promotes the conversion of round spermatids between stages VII and VIII of the rat spermatogenic cycle Endocrinology 135 2608-2614

Onyango DW, Gachoka JM, Otianga-Owiti GE and Hendrickx AG (1995) Seasonally dependent testicular apoptosis in the tropical long-fingered bat (Miniopterus inflatus). Zeitschrift für Sängetierkunde 60 206-214 
Sauerwein H and Meyer HHD (1989) Androgen and estrogen receptors in bovine skeletal muscle - relation to steroid induced allometric muscle growth Journal of Animal Science 67 206-212

Sauerwein H, Dürsch I and Meyer HHD (1991) Quantification of glucocorticoid receptors in bovine skeletal muscles: topographical distribution, sex effect and breed comparisons Journal of Steroid Biochemistry 39 941-945

Schams D and Barth D (1982) Annual profiles of reproductive hormones in peripheral plasma of the male roe deer Capreolus capreolus. Journal of Reproduction and Fertility 66 463-468

Sempéré AJ and Boissin J (1981) Relationship between antler development and plasma androgen concentrations in adult roe deer (Capreolus capreolus). Journal of Reproduction and Fertility 62 49-53

Sempéré AJ, Mauget R and Bubenik GA (1992) Influence of photoperiod on the seasonal pattern of secretion of luteinizing hormone and testosterone and on the antler cycle in roe deer Journal of Reproduction and Fertility 95 693-700

Sinha Hikim AP, Wang C, Leung A and Swerdloff RS (1995) Involvement of apoptosis in the induction of germ cell degeneration in adult rats after gonadotropin-releasing hormone antagonist treatment Endocrinology 136 $2770-2775$

Steger K, Schimmel M and Wrobel KH (1994) Immunocytochemical demonstration of cytoskeletal proteins in seminiferous tubules of adult rams and bulls Archives of Histology and Cytology 57 17-28

Stieve H (1950) Anatomisch-biologische Untersuchungen über die Fortpflanzungsfähigkeit des europäischen Rehes (Capreolus capreolus L). Zeitschrift für Mikroskopisch-anatomische Forschung 55 427-528

Suresh R, Aravindan GR and Moudgal NR (1992) Quantitation of spermatogenesis by DNA flow cytometry: comparative study among six species of mammals Journal of Biosciences 17 413-419
Suresh R, Medhamurthy R and Moudgal NR (1995) Comparative studies on the effects of specific immunoneutralisation of endogenous $\mathrm{FSH}$ or $\mathrm{LH}$ on testicular germ cell transformation in the adult bonnet monkey (Macasa radiata). American Journal of Reproductive Immunology 34 35-43

Tapanainen JS, Tilly JL, Vihko KK and Hsueh AWJ (1993) Hormonal control of apoptotic cell death in the testis: gonadotropins and androgens as testicular survival factors Molecular Endocrinology 7 643-650

Tejada RI, Mitchell JC, Norman A, Marik JJ and Friedman S (1984) A test for practical evaluation of male fertility by acridine orange $(\mathrm{AO})$ fluorescence Fertility and Sterility $\mathbf{4 2} 87-91$

Tenniswood MP, Guenette RS, Lakins J, Mooibroek M, Wong P and Welsh JE (1992) Active cell death in hormone-dependent tissue Cancer Metastasis Review 11 197-220

Thompson EB (1994) Apoptosis and steroid hormones Molecular Endocrinology 8 665-673

Troiano L, Fustini MF, Lovato E, Frasoldati A, Malorni W, Capri M, Grassilli E, Marrama P and Franceschi C (1994) Apoptosis and spermatogenesis: evidence from an in vivo model of testosterone withdrawal in the adult rat Biochemical and Biophysical Research Communication 202 13151321

Vaishnav M and Moudgal NR (1994) Role of FSH in regulating testicular germ cell transformations in the rat: a study using DNA flow cytometry Andrologia 26 111-117

Van Haaster LH, van Eerdenburg FJCM and de Rooij DG (1993) Effect of prenatal and postnatal photoperiod on spermatogenic development in the Djungarian hamster (Phodopus sungorus sungorus). Journal of Reproduction and Fertility 97 223-232 